\title{
Changes in the levels of T lymphocytes and inflammatory factors in the peripheral blood of breast cancer patients during postoperative chemotherapy
}

\author{
Cunliang Wang ${ }^{1,2}$, Wei Han $^{3}$, Yuanting Gu${ }^{1}$ \\ ${ }^{1}$ Department of Breast Surgery, the First Affiliated Hospital of Zhengzhou University, Zhengzhou, China; ${ }^{2}$ Medical Service, the First Affiliated Hospital \\ of Zhengzhou University, Zhengzhou, China; ${ }^{3}$ Quality Control Division, the First Affiliated Hospital of Zhengzhou University, Zhengzhou, China \\ Contributions: (I) Conception and design: C Wang, Y Gu; (II) Administrative support: W Han; (III) Provision of study materials or patients: C Wang, \\ W Han; (IV) Collection and assembly of data: All authors; (V) Data analysis and interpretation: C Wang, Y Gu; (VI) Manuscript writing: All authors; \\ (VII) Final approval of manuscript: All authors. \\ Correspondence to: Yuanting Gu. Department of Breast Surgery, the First Affiliated Hospital of Zhengzhou University, 1st Jianshe Dong Lu, \\ Zhengzhou 450052, China. Email: zdyfysci@163.com.
}

Background As one of the main malignant tumors affecting women, the incidence of breast cancer increases year by year. This study aims to analyze the risk factors of infection in breast cancer patients during postoperative chemotherapy by measuring the changes in the levels of $\mathrm{T}$ lymphocytes and inflammatory factors in peripheral blood.

Methods: The clinical data of 156 patients who underwent radical mastectomy and postoperative chemotherapy [docetaxel, epirubicin, cyclophosphamide (TEC)] in our hospital from May 2014 to April 2018 were retrospectively analyzed. According to the presence or absence of infection after chemotherapy, patients were divided into the infection group and the normal group. The risk factors of infection during chemotherapy were analyzed by univariate and multiple logistic regression analyses. Serum before surgery, and before and after chemotherapy, was collected to detect the levels of $\mathrm{T}$ lymphocytes and inflammatory factors.

Results: A total of 36 patients developed an infection during chemotherapy, with an infection rate of $23.08 \%$. The main infection site was the respiratory tract. The main pathogens detected were Gramnegative bacteria and Gram-positive bacteria. The results of univariate analysis showed that there were significant differences in age, diabetes mellitus, clinical TNM staging, white blood cell count (WBC), T lymphocyte subsets $\mathrm{CD}^{+} / \mathrm{CD}^{+}, \mathrm{C}$-reactive protein (CRP) levels, and tumor necrosis factor- $\alpha(\mathrm{TNF}-\alpha)$ levels between the 2 groups $(\mathrm{P}<0.05)$. Results of logistic regression analysis showed that age $\geq 60$ years old, diabetes mellitus, clinical TNM staging $\geq$ stage III, WBC $<3.5 \times 10^{9} / \mathrm{L}, \mathrm{CD}^{+} / \mathrm{CD}^{+}<1.33$, TNF $-\alpha \geq 70 \mathrm{ng} / \mathrm{L}$ and CRP $\geq 60 \mathrm{mg} / \mathrm{L}$ were all independent risk factors of postoperative infection $(\mathrm{P}<0.05)$. Both before and after chemotherapy, levels of $\mathrm{CD}^{+}, \mathrm{CD}^{+} \mathrm{CD}^{+}$and $\mathrm{CD}^{+} / \mathrm{CD}^{+}$cells in the infection group were significantly lower than those in the normal group, while levels of CRP, TNF- $\alpha$ and IL-6 were significantly higher than those in the normal group $(\mathrm{P}<0.05)$.

Conclusions: Dynamic monitoring of changes in the levels of $\mathrm{T}$ lymphocytes and inflammatory factors during chemotherapy may be of clinical value for predicting the risk of infection. Implementing targeted intervention measures for these risk factors may therefore be beneficial for controlling infection.

Keywords: Breast cancer; radical surgery; chemotherapy; infection

Submitted Oct 18, 2020. Accepted for publication Dec 08, 2020.

doi: $10.21037 /$ gs-20-818

View this article at: http://dx.doi.org/10.21037/gs-20-818 


\section{Introduction}

Breast cancer is one of the main malignant tumors that poses a significant threat to women's health, with an increasing incidence year by year (1). In the treatment of breast cancer, more than $5 \%$ of patients present with distant metastasis at the time of first clinical diagnosis, and $50 \%$ of patients will still undergo relapse and metastasis after treatment $(2,3)$. At present, adjuvant chemotherapy after radical mastectomy is the main treatment approach for breast cancer, which can not only improve the longterm survival rate of patients, but also reduce the chance of recurrence. However, patients with breast cancer are in an immunosuppressive state. Radical mastectomy is a kind of treatment with surface wound, and larger surgical procedures will suppress the immune system. Additionally, chemotherapy drugs can often cause varying degrees of damage to the body's immune cells. Therefore, patients with breast cancer are prone to infection during chemotherapy after radical surgery, which is not conducive to the treatment and prognosis of the disease (4).

As the most important and complex cells of the adaptive immune system, $\mathrm{T}$ lymphocytes participate in processes such as tumor immune surveillance, tumor cell killing and immune regulation. According to the different cluster of differentiation (CD) phenotypes, $\mathrm{T}$ lymphocytes can be divided into $\mathrm{CD}^{+}$(helper T cells) and $\mathrm{CD}^{+}$(cytotoxic $\mathrm{T}$ cells). Under healthy conditions, the ratio of $\mathrm{CD} 4^{+}$ and $\mathrm{CD}^{+}$is in a relatively balanced state to maintain the stability of immune function, hence the $\mathrm{CD} 4^{+} / \mathrm{CD}^{+}$ratio is often used to reflect the body's immune function (5). During an inflammatory response, especially with bacterial infections, factors such as interleukin-6 (IL-6), C-reactive protein (CRP), and tumor necrosis factor- $\alpha$ (TNF- $\alpha$ ) increase. Therefore, the levels of these inflammatory factors can reflect the infection status of the body to a certain extent (6).

In this study, we analyzed the clinical data of 156 breast cancer patients to explore the risk factors for infection during chemotherapy, along with changes in peripheral blood $\mathrm{T}$ lymphocytes and inflammatory factor levels. We therefore propose targeted intervention measures for infection in breast cancer patients during postoperative chemotherapy. We present the following article in accordance with the STROBE reporting checklist (available at http://dx.doi.org/10.21037/gs-20-818).

\section{Methods}

\section{Clinical data}

The clinical data of 156 breast cancer patients who underwent chemotherapy in our hospital from May 2014 to April 2018 were retrospectively analyzed. All patients met the diagnostic criteria for breast cancer (7) and underwent radical mastectomy, and received adjuvant treatment with postoperative chemotherapy. The exclusion criteria were as follows: (I) patients with preoperative or prechemotherapy infection; (II) patients with severe heart, liver, or kidney dysfunction; (III) patients who had recently taken immunosuppressive agents or immunomodulators; (IV) patients with acute local inflammation or systemic inflammation. All patients were female, aged 41 to 69 years, with an average age of 52.6 \pm 9.1 years. There were 105 cases of invasive ductal carcinoma, 27 cases of invasive lobular carcinoma, and 24 cases of mixed cancer, and 19 cases were at TNM stage I, 121 were at stage II, and the remaining 16 cases were at stage III. As for the complications, there were 21 cases with diabetes, 35 cases with hypertension, and 82 cases with cardiovascular disease. All procedures performed in this study involving human participants were in accordance with the Declaration of Helsinki (as revised in 2013). The study was approved by the First Affiliated Hospital of Zhengzhou University (NO.: 2020-KY-0119). Individual consent for this retrospective analysis was waived.

\section{Research methods}

According to their status, patients were treated with modified radical mastectomy, breast-conserving radical mastectomy, or simple breast resection + sentinel lymph biopsy. A docetaxel + epirubicin + cyclophosphamide (TEC) chemotherapy regimen was administered after surgery. Chemotherapy was performed for 6 cycles, with 21 days for each cycle, and each time lasted for 1 day. During chemotherapy, saliva and blood were collected for cell testing, and the "Diagnostic Standards for Nosocomial Infection" (8) formulated by the Ministry of Health was used to determine whether or not the patient had an infection.

\section{Observation indicators}

Fasting venous blood $(3 \mathrm{~mL})$ was collected in EDTA 
Table 1 Univariate analysis of infection in breast cancer patients during postoperative chemotherapy

\begin{tabular}{|c|c|c|c|c|}
\hline Factor & Infection group $(n=36)$ & Normal group $(n=120)$ & Statistics & $\mathrm{P}$ \\
\hline Combined diabetes (yes/no) & $15 / 21$ & $6 / 114$ & 31.754 & $<0.001$ \\
\hline Clinical TNM staging & & & 21.505 & $<0.001$ \\
\hline Stage I & 3 & 16 & & \\
\hline Stage III & 14 & 2 & & \\
\hline WBC $\left(10^{9} / \mathrm{L}\right)$ & $3.17 \pm 0.12$ & $3.75 \pm 0.17$ & 19.074 & $<0.001$ \\
\hline $\mathrm{CD}^{+} / \mathrm{CD}^{+}$ & $1.18 \pm 0.04$ & $1.34 \pm 0.06$ & 15.013 & $<0.001$ \\
\hline TNF- $\alpha$ (ng/L) & $86.41 \pm 13.94$ & $60.28 \pm 9.23$ & 13.111 & $<0.001$ \\
\hline
\end{tabular}

WBC, white blood cell count; CRP, C-reactive protein.

anticoagulation tubes from all patients before surgery, as well as before and after chemotherapy. The blood was refrigerated at $4{ }^{\circ} \mathrm{C}$ for inspection without coagulation or hemolysis. The lymphocyte subset detection kit (BD Company, USA) and MultiSET software were used to detect and analyze the levels of $\mathrm{CD}^{+}, \mathrm{CD}^{+}{ }^{+} \mathrm{CD}^{+}, \mathrm{CD}^{+}{ }^{+} \mathrm{CD} 8^{+}$, $\mathrm{CD}^{+} / \mathrm{CD}^{+}$cells in peripheral blood. The levels of IL-6, $\mathrm{CRP}$, and TNF- $\alpha$ in peripheral blood were detected using enzyme-linked immunosorbent assay (ELISA), with all the ELISA kits provided by Beijing Lvyuan Bird Biotechnology Company (Beijing, China).

\section{Statistical methods}

All data was analyzed using SPSS 17.0 software (IBM, USA). Count data was expressed as rate and analyzed using a chi-square $\left(\chi^{2}\right)$ test. Measurement data conforming to the normal distribution was expressed as the mean \pm standard deviation, and analyzed using a t-test for comparisons between 2 groups. The multivariate analysis was performed by stepwise multiple logistic regression analysis. Results with $\mathrm{P}<0.05$ were considered to be statistically significant.

\section{Results}

\section{Infection status of the patients}

Among the 156 patients, 36 patients developed an infection during chemotherapy, with an infection rate of $23.08 \%$. The main infection sites were the oral cavity and the respiratory tract, accounting for $47.22 \%(17 / 36)$ and $33.33 \%(12 / 36)$ of cases, respectively. A total of 42 strains of pathogenic bacteria were detected, and Gram-negative bacteria and Gram-positive bacteria were the main pathogens detected, accounting for $47.62 \%(20 / 42)$ and $33.33 \%$ (14/42) of cases, respectively.

\section{Univariate analysis of infection in breast cancer patients during postoperative chemotherapy}

The results of the univariate analysis showed that there were significant differences between the 2 groups in factors such as age, combined with diabetes, clinical TNM stage, white blood cell count (WBC), T lymphocyte subsets $\mathrm{CD}^{+} / \mathrm{CD}^{+}, \mathrm{TNF}-\alpha$, and $\mathrm{CRP}(\mathrm{P}<0.05$, Table 1$)$.

\section{Multiple logistic regression analysis of infection during postoperative chemotherapy in breast cancer patients}

The postoperative infection outcome was used as the dependent variable (setting 0 for normal, and 1 for infection), and risk factors including age ( $<60$ years old assigned as $0, \geq 60$ years old as 1 ), combined with diabetes (not combined as 0 , combined as 1 ), TNM staging (stage I or II assigned as 0 , stage III as 1$)$, WBC $\left(\geq 3.5 \times 10^{9} / \mathrm{L}\right.$ assigned as $0,<3.5 \times 10^{9} / \mathrm{L}$ as 1$), \mathrm{CD}^{+} / \mathrm{CD}^{+}(\geq 1.33$ assigned as $0,<1.33$ as 1$)$, TNF- $\alpha(<70 \mathrm{ng} / \mathrm{L}$ assigned as $0, \geq 70 \mathrm{ng} / \mathrm{L}$ as 1 ), and CRP ( $<60 \mathrm{mg} / \mathrm{L}$ assigned as $0, \geq 60 \mathrm{mg} / \mathrm{L}$ as 1) were used as independent variables. Multiple logistic stepwise regression analysis was then performed, and the 
Table 2 Multiple logistic regression analysis of infection in breast cancer patients during postoperative chemotherapy

\begin{tabular}{lcccccc}
\hline Factor & Regression coefficient & SEM & Wald $\chi^{2}$ & $\mathrm{P}$ & OR & 95\% Cl \\
\hline Aged $\geq 60$ years & 0.935 & 0.311 & 9.039 & 0.003 & 2.547 & $1.385-4.686$ \\
Combined diabetes & 0.834 & 0.296 & 7.939 & 0.005 & 2.303 & $1.289-4.113$ \\
Clinical TNM staging $\geq$ stage III & 0.684 & 0.235 & 8.472 & 0.004 & 1.982 & $1.250-3.141$ \\
WBC $<3.5 \times 10^{9} / \mathrm{L}$ & 0.432 & 0.216 & 4.000 & 0.046 & 1.540 & $1.009-2.352$ \\
$\mathrm{CD}^{+} / \mathrm{CD} 8^{+}<1.33$ & 0.765 & 0.308 & 6.169 & 0.013 & 2.149 & $1.175-3.930$ \\
$\mathrm{TNF}-\alpha \geq 70 \mathrm{ng} / \mathrm{L}$ & 0.594 & 0.263 & 5.101 & 0.024 & 1.811 & $1.082-3.033$ \\
$\mathrm{CRP} \geq 60 \mathrm{mg} / \mathrm{L}$ & 1.238 & 0.439 & 7.953 & 0.005 & 3.449 & $1.459-8.153$ \\
\hline
\end{tabular}

SEM, Standard error of the mean; WBC, white blood cell count.

Table 3 Comparison of serum T lymphocyte levels before and after chemotherapy between the 2 groups

\begin{tabular}{|c|c|c|c|c|c|}
\hline Indicators & Period & Infection group ( $\mathrm{n}=36$ ) & Normal group $(n=120)$ & $\mathrm{t}$ value & $P$ value \\
\hline $\mathrm{CD3}^{+}(\%)$ & After chemotherapy & $61.08 \pm 2.86$ & $65.35 \pm 3.17$ & 7.243 & $<0.001$ \\
\hline \multirow[t]{2}{*}{$\mathrm{CD}^{+} \mathrm{CD}^{+}(\%)$} & Before chemotherapy & $31.26 \pm 4.48$ & $35.49 \pm 5.61$ & 4.142 & $<0.001$ \\
\hline & After chemotherapy & $24.19 \pm 2.67$ & $29.62 \pm 3.49$ & 8.603 & $<0.001$ \\
\hline $\mathrm{CD}^{+} \mathrm{CD}^{+}(\%)$ & After chemotherapy & $24.31 \pm 3.74$ & $24.36 \pm 4.13$ & 0.065 & 0.065 \\
\hline \multirow[t]{2}{*}{$\mathrm{CD}^{+} / \mathrm{CD}^{+}$} & Before chemotherapy & $1.08 \pm 0.25$ & $1.36 \pm 0.27$ & 4.993 & $<0.001$ \\
\hline & After chemotherapy & $0.76 \pm 0.14$ & $1.18 \pm 0.21$ & 11.260 & $<0.001$ \\
\hline
\end{tabular}

results showed that age $\geq 60$ years old, combined with diabetes, clinical TNM staging $\geq$ stage III, use of triple antibiotics, $\mathrm{WBC}<3.5 \times 10^{9} / \mathrm{L}, \mathrm{CD}^{+} / \mathrm{CD}^{+}<1.33, \mathrm{TNF}-\alpha$ $\geq 70 \mathrm{ng} / \mathrm{L}$, and CRP $\geq 60 \mathrm{mg} / \mathrm{L}$ were independent risk factors for postoperative infection in breast cancer patients $(\mathrm{P}<0.05$, Table 2).

\section{Comparison of serum $T$ lymphocytes before and after chemotherapy in the 2 groups}

The levels of $\mathrm{CD}^{+}, \mathrm{CD}^{+}{ }^{+} \mathrm{CD} 4^{+}$, and $\mathrm{CD} 4^{+} / \mathrm{CD}^{+}$cells in the infection group before and after chemotherapy were significantly lower compared to the normal group $(\mathrm{P}<0.05)$, while the level of $\mathrm{CD}^{+}{ }^{+} \mathrm{CD} 8^{+}$cells was not statistically different from the normal group $(\mathrm{P}>0.05$, Table 3$)$.

\section{Comparison of serum inflammatory factor levels before and after chemotherapy in the 2 groups}

Results showed that the levels of CRP, TNF- $\alpha$, and
IL-6 in patients in the infection group before and after chemotherapy were significantly higher than the normal group $(\mathrm{P}<0.05$, Table 4).

\section{Discussion}

Lymphatic vessel obstruction, tumor cell invasion, and damage to the body's anatomical barriers during radical mastectomy are all causes of reduced immunity in breast cancer patients. In order to improve the survival rate of patients and reduce the recurrence rate after surgery, adjuvant chemotherapy is usually administered to stabilize the disease. However, most chemotherapeutic drugs will inhibit granulocyte production to varying degrees, further reducing immunity. Hence, breast cancer patients undergoing chemotherapy are at a high-risk of nosocomial infections $(9,10)$. In this study, there were 36 cases among the total of 156 breast cancer patients who developed infections during chemotherapy, and the respiratory tract was the main infection site. The use of chemotherapy 
Table 4 Comparison of serum inflammatory factor levels before and after chemotherapy between the 2 groups

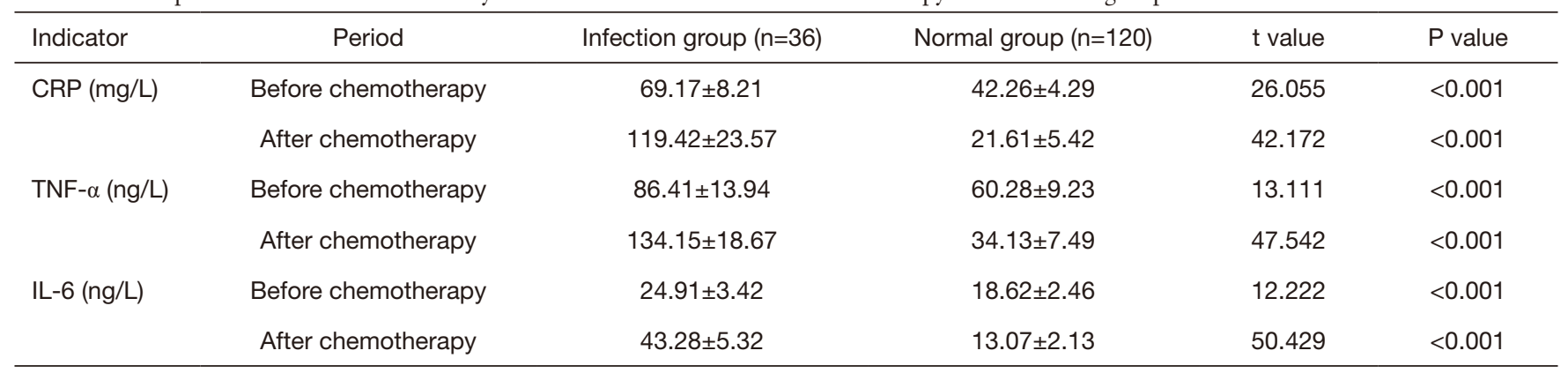

CRP, C-reactive protein.

drugs and immunosuppressive agents decrease the levels of globulin IgA in the airway mucosa. Thus, respiratory ciliary clearance mechanisms and local immune screens are reduced, and pathogens are more likely to invade the respiratory tract and cause infection in the airway mucosa (11). Furthermore, the hospital is a special place with a much higher probability of pathogenic bacteria than that of other places, and from the detection of pathogenic bacteria in infected patients, the results indicated that most of the pathogens are multi-conditional pathogens. It can be seen that infection is mostly endogenous, and that in addition to the decrease in immunity, the application of a large number of antibiotics and hormones will also cause an imbalance of bacteria in the body and increase the risk of infection (12).

In this study, the results of the univariate analysis and the multivariate logistic regression analysis found that factors such as age $\geq 60$ years old, diabetes, clinical TNM staging $\geq$ stage III, $\mathrm{WBC}<3.5 \times 10^{9} / \mathrm{L}, \mathrm{CD}^{+} / \mathrm{CD}^{+}<1.33, \mathrm{TNF}-\alpha$ $\geq 70 \mathrm{ng} / \mathrm{L}$ and $\mathrm{CRP} \geq 60 \mathrm{mg} / \mathrm{L}$ were all independent risk factors for postoperative infection. With increasing age, the body's functioning gradually declines, especially the immune system. Studies have shown that the level of $\mathrm{CD}^{+}$ cells decreased in the peripheral blood of breast cancer patients aged $>55$ years, while the level of B cells increased, suggesting that it is necessary to pay more attention to the immune function of elderly patients during the processes of clinical diagnosis and treatment. During treatment, the use of immunosuppressive drugs should be reduced and immunotherapy should be strengthened (13). Incision infection is more likely to occur in patients with diabetes, as the immunity of patients with diabetes is often impaired. Furthermore, the environment of high blood sugar in diabetic patients provides suitable growth conditions for pathogenic bacteria, and incision in diabetic patients is not easy to heal after surgery (14). As for the influence of TNM stage, the higher the clinical TNM stage, the higher the degree of tumor invasion and metastasis to the lymph nodes, which may cause lymphatic blockage, impair immunity, and increase the risk of infection. Previous studies have shown that the infection rates of patients with $\mathrm{WBC} \leq 1 \times 10^{9} / \mathrm{L}$, $1 \times 10^{9}-4 \times 10^{9} / \mathrm{L}$, and $4 \times 10^{9}-10 \times 10^{9} / \mathrm{L}$ are $22.11 \%, 18.52 \%$, and $8.24 \%$, respectively (15), indicating that the lower the WBCs, the higher the probability of infection. In this study, we found that the level of WBCs in the peripheral blood of patients with an infection during chemotherapy was significantly lower than that of patients without an infection, further confirming that a decrease of WBCs is a risk factor for infection in breast cancer patients during treatment with chemotherapy. Immunity is often determined by different subgroups of $\mathrm{T}$ lymphocytes. The ratio of $\mathrm{CD} 4^{+} / \mathrm{CD} 8^{+}$ cells is an important indicator reflecting the balance of $\mathrm{T}$ lymphocyte subgroups, and remains constant between 1.5 and 2.0 in the healthy body. However, the ratio of $\mathrm{CD}^{+} /$ $\mathrm{CD}^{+}$cells in breast cancer patients is seriously imbalanced, causing impaired immune function, thereby increasing the likelihood of invasion by pathogenic bacteria (16). TNF- $\alpha$ is a type of pro-inflammatory cytokine secreted by Th1 cells, and high levels of TNF- $\alpha$ are conducive to tumor growth. When pathogenic bacteria invade, TNF- $\alpha$ levels increase, therefore high levels of TNF- $\alpha$ may be a biological indicator of the occurrence of infection (17). CRP is a protein that is indicative of an inflammatory response, and can increase rapidly when the body is injured or undergoes certain inflammatory changes (18). Studies have shown that increased levels of CPR can be detected before the occurrence of clinical symptoms of infection in patients, so a high level of CRP in patients can indicate that the patient has an infection (19). In view of the risk factors mentioned above for infection in breast cancer patients during postoperative chemotherapy, corresponding intervention 
strategies can be adopted to reduce infection rates as follows: (I) for elderly or immunocompromised patients, nutritional support and immune-enhancing drugs are required during chemotherapy. At the same time, for basic diseases such as diabetes, blood sugar levels should be controlled as much as possible, and the length of hospitalization should be reduced as much as possible to decrease the chance of contact with pathogenic bacteria; (II) aseptic operation procedures in the treatment and nursing process should be strengthened, and antibiotics need to be used in a reasonable and appropriate amount strictly according to the chemotherapy regimen and the results of drug sensitivity tests; (III) close attention should be paid to the blood biochemical indicators of the patients. As chemotherapy causes the suppression of bone marrow, patients with WBC $<1 \times 10^{9} / \mathrm{L}$ should be treated with a lower dose of pharmaceutical drugs. In this study, by measuring $\mathrm{T}$ lymphocytes and inflammatory factors in patients before and after chemotherapy, results showed that the levels of $\mathrm{CD}^{+}, \mathrm{CD}^{+}{ }^{+} \mathrm{CD} 4^{+}$cells, and the ratio of $\mathrm{CD} 4^{+} / \mathrm{CD} 8^{+}$cells in the peripheral blood of patients in the infection group were significantly lower than those in the normal group both before and after chemotherapy, suggesting that low immunity before chemotherapy will increase the risk of infection, and the occurrence of infection will further suppress the body's immune response. At the same time, this study also found that serum CRP, TNF- $\alpha$, and IL-6 levels in patients in the infection group before and after chemotherapy were significantly higher than those in the normal group, indicating that high levels of inflammatory factors may have a certain predictive value for infection during chemotherapy.

In summary, breast cancer patients have low immunity during adjuvant chemotherapy after surgery, making them a high-risk group for infection. Dynamic monitoring of changes in $\mathrm{T}$ lymphocytes and levels of inflammatory factors may have clinical value for predicting infection during chemotherapy after surgery. This may also help to reduce and control infections by developing and implementing targeted intervention measures for the risk factors of infection.

\section{Acknowledgments}

Funding: None.

\section{Footnote}

Reporting Checklist: The authors have completed the
STROBE reporting checklist. Available at http://dx.doi. org/10.21037/gs-20-818

Data Sharing Statement: Available at http://dx.doi. org/10.21037/gs-20-818

Conflicts of Interest: All authors have completed the ICMJE uniform disclosure form (available at http://dx.doi. org/10.21037/gs-20-818). The authors have no conflicts of interest to declare.

Ethical Statement: The authors are accountable for all aspects of the work in ensuring that questions related to the accuracy or integrity of any part of the work are appropriately investigated and resolved. All procedures performed in this study involving human participants were in accordance with the Declaration of Helsinki (as revised in 2013). The study was approved by the First Affiliated Hospital of Zhengzhou University (NO.: 2020-KY-0119). Individual consent for this retrospective analysis was waived.

Open Access Statement: This is an Open Access article distributed in accordance with the Creative Commons Attribution-NonCommercial-NoDerivs 4.0 International License (CC BY-NC-ND 4.0), which permits the noncommercial replication and distribution of the article with the strict proviso that no changes or edits are made and the original work is properly cited (including links to both the formal publication through the relevant DOI and the license). See: https://creativecommons.org/licenses/by-nc-nd/4.0/.

\section{References}

1. Merrick HW 3rd, Hager E, Dobelbower RR Jr. Intraopertive radiation therapy for breast cancer. Surg Oncol Clin N Am 2003;12:1065-78.

2. Hosseini H, Obradović MMS, Hoffmann M, et al. Early dissemination seeds metastasis in breast cancer. Nature 2016;540:552-8.

3. Sugie T. Immunotherapy for metastatic breast cancer. Chin Clin Oncol 2018;7:28.

4. Slaney CY, Rautela J, Parker BS. The emerging role of immunosurveillance in dictating metastatic spread in breast cancer. Cancer Res 2013;73:5852-7.

5. Huang W, Liu J, Zeng Y, et al. Randomized controlled clinical trial of polyethylene glycol recombinant human granulocyte colony-stimulating factor in the treatment of neutropenia after chemotherapy for breast cancer. Cancer 
Chemother Pharmacol 2018;82:607-13.

6. Kopf JC, Suhr MJ, Clarke J, et al. Role of whole grains versus fruits and vegetables in reducing subclinical inflammation and promoting gastrointestinal health in individuals affected by overweight and obesity: a randomized controlled trial. Nutr J 2018;17:72.

7. Hopwood P, Haviland JS, Sumo G, et al. Comparison of patient-reported breast, arm, and shoulder symptoms and body image after radiotherapy for early breast cancer: 5 -year follow-up in the randomised Standardisation of Breast Radiotherapy (START) trials. Lancet Oncol 2010;11:231-40.

8. Manquat G. Infections nosocomiales. Nosocomial infections. Epidemiology, diagnostic criteria, prevention, treatment principles. Rev Prat 2000;50:641-6.

9. Bhatt ST, Bednarski JJ, Berg J, et al. Immune Reconstitution and Infection Patterns after Early Alemtuzumab and Reduced Intensity Transplantation for Nonmalignant Disorders in Pediatric Patients. Biol Blood Marrow Transplant 2019;25:556-61.

10. Chidambaram R, Terunuma H, Balamurugan $M$, et al. Cell-based immunotherapy in stage IIIA inflammatory breast cancer with declining innate immunity following successive chemotherapies: A case report. Mol Clin Oncol 2017;7:493-7.

11. Masoud V, Pagès G. Targeted therapies in breast cancer: New challenges to fight against resistance. World J Clin Oncol 2017;8:120-34.

Cite this article as: Wang C, Han W, Gu Y. Changes in the levels of $\mathrm{T}$ lymphocytes and inflammatory factors in the peripheral blood of breast cancer patients during postoperative chemotherapy. Gland Surg 2020;9(6):2155-2161. doi: 10.21037 /gs-20-818
12. Su Y, Tang LY, Chen LJ, et al. Joint effects of febrile acute infection and an interferon- $\gamma$ polymorphism on breast cancer risk. PLoS One 2012;7:e37275.

13. Huang Y, Ma C, Zhang Q, et al. CD4+ and CD8+ T cells have opposing roles in breast cancer progression and outcome. Oncotarget 2015;6:17462-78.

14. Martin ET, Kaye KS, Knott C, et al. Diabetes and Risk of Surgical Site Infection: A Systematic Review and Metaanalysis. Infect Control Hosp Epidemiol 2016;37:88-99.

15. Crouser ED, Parrillo JE, Seymour C, et al. Improved Early Detection of Sepsis in the ED With a Novel Monocyte Distribution Width Biomarker. Chest 2017;152:518-26.

16. Dias Rodrigues V, Barroso de Pinho N, et al. Nutrition and Immune-Modulatory Intervention in Surgical Patients With Gastric Cancer. Nutr Clin Pract 2017;32:122-9.

17. Babaei Z, Moslemi D, Parsian H, et al. Relationship of obesity with serum concentrations of leptin, CRP and IL-6 in breast cancer survivors. J Egypt Natl Canc Inst 2015;27:223-9.

18. Allin KH, Nordestgaard BG. Elevated C-reactive protein in the diagnosis, prognosis, and cause of cancer. Crit Rev Clin Lab Sci 2011;48:155-70.

19. Alcoba G, Keitel K, Maspoli V, et al. A three-step diagnosis of pediatric pneumonia at the emergency department using clinical predictors, C-reactive protein, and pneumococcal PCR. Eur J Pediatr 2017;176:815-24.

(English Language Editor: C. Betlazar-Maseh) 